\title{
The Factors that may attract Petra Christian University Students as a New Target Market to visit Seventeen Skyview Resto \& Lounge of Harris-Pop! Hotels \& Conventions on Weekdays
}

\author{
Stefanie Lawrence \\ English Department, Faculty of Languages and Literature, Petra Christian University, Siwalankerto 121- \\ 131, Surabaya 60236, INDONESIA \\ E-mail: m11415063@john.petra.ac.id
}

\begin{abstract}
This project aims to solve the problem regarding the low number of customers coming to Seventeen Skyview Resto \& Lounge on weekdays. I intended to conduct an in-depth research, with the objective is to identify the factors that can be used to attract the new target market to come to this restaurant on weekdays. The main tool I used on this research is the questionnaire form, and the main respondents of this research are fifty students from seventeen different majors in Petra Christian University. The final outcome of this project is a research report as the summary of the questionnaire forms that have been filled out by fifty students of Petra Christian University. This research report will be a beneficial tool for the restaurant to understand the perspectives of Petra Christian University students, who can be categorized as the new potential target market for this restaurant to come on weekdays.
\end{abstract}

Keywords: Research, Respondents, Questionnaire Form, Report

\section{INTRODUCTION}

The name of the company where I did my internship is HARRIS-POP! Hotels and Conventions. This hotel is located in the east area of Surabaya, which is in Jl. Bangka, Gubeng. Combining two brands of hotels in one land, HARRIS-POP! Hotels and Conventions has become the first and only hotel in Surabaya with the combo-hotel concept. As a hotel, the main product of HARRIS-POP! Hotels \& Conventions is the rooms it provides for the guests. In addition, this hotel is also facilitated with a variety of amenities, such as rooms for seminars and meetings, ballrooms, swimming pool, gym center, kids club, boutique, cake shop, café, restaurant and spa. Even though HARRIS and POP! Hotels are built in one land and are under the same hotel management, each hotel has its own specification, concept and facilities. HARRIS Hotel \& Conventions is certified as a 4-star hotel according to the Tauzia Hotel Management as the parent company; while, POP! Hotel is certified as a 2-star hotel, two stars below HARRIS. The concept of combo-hotel that HARRIS-POP! Hotels \& Conventions has brought to the society is a brand new concept to serve the people from low, middle to upper class society, so that they can choose by themselves in which hotel they feel most comfortable and suitable with their needs. As of today, the hotels that can be considered as the competitors of HARRIS-POP! Hotels \& Conventions are Santika Premier Hotel, Mercure Grand Mirama, Grand Darmo Suites, Novotel Surabaya Hotel \& Suites, and the newest one is Grand Dafam Hotel. Those hotels are considered as the competitors of HARRIS-POP! Hotels \& Conventions because they are located near to each other, are the most known 4-star hotels in Surabaya and are able to get similar percentage of the monthly room occupancy level as well as the revenue. Led by one General Manager for HARRIS Hotel, and one Hotel Manager for POP! Hotel, this hotel has a total of eleven departments, each with different Head of Departments (HOD) and number of staffers.

During the four months of internship I spent in this hotel, I have noticed both the strengths and drawbacks of this hotel. The main problem that I think is quite serious and needs an urgent 
response in the daily operation of this hotel is the low number of customers coming to Seventeen Skyview Resto \& Lounge on weekdays. Seventeen Skyview Resto \& Lounge is a restaurant in HARRIS-POP! Hotels \& Conventions that has the exclusive and expensive concept with a la carte menus and alcoholic drinks as the main product. However, for the last few months, the performance of this restaurant is becoming weaker than expected. This restaurant is only crowded on weekends, especially on Sundays because they have the All-YouCan-Eat Dimsum. Nevertheless, according to the interview I have done with the manager, supervisor and admin of this restaurant, there are only approximately one, two or even none of the customers coming to the restaurant on weekdays, and this has caused them to not being able to reach their target revenue every month because they still have to pay for the operational cost of this restaurant on weekdays as well as to give salaries to the waitresses and waiters.

Nevertheless, there are several possible causes for this problem. First of all, the manager mentioned market review as one of the possible causes for the problem I found. It refers to the needs of people that keep on changing, people nowadays need a place that can provide them with good ambience, affordable products, live music (if possible), and an instagram-able spot to take photos. These elements are still missing in Seventeen Lounge Skyview \& Resto. Second, it is because they have not specified who should be the target market of this restaurant on weekdays. Therefore, they cannot classify what kind of special offers and promotional tools to be used to gain more customers and overcome the restaurant's poor performance on weekdays. The admin of the restaurant could only mention a very general category of target market, instead of a specific one that they can attract specifically on weekdays. Third, they have never conducted a survey to check the customers' feedback for the overall performance of this restaurant, which I think is a very important deal to measure and improve the overall performance, and to know how to better serve the customers in the future. Also, this restaurant rarely gives special offers or interesting promotions, that is supposed to be one way to attract the different social classes, especially those who do not have the courage to come to this place because of the expensive and exclusive concept. As a result, the balance cost of the products sold on this restaurant is always below the budget as they can only get much income on weekends, yet they still have to cover all the budget and expenses of the restaurant both on weekends and weekdays.

Along with those facts, the writer has intended to conduct an in-depth research using questionnaire forms as the main tool and the students of Petra Christian University as the main respondents. There are three reasons for choosing the students of Petra Christian University to be the respondents for this project. First of all, Petra Christian University is among the best and oldest private universities in Indonesia. It means that this university has a wide range of network, from the current students and staffers to the alumni. Therefore, the restaurant will be able to get a new source and media to gain new target market and possible loyal customers. Second, since the preferred target market of this restaurant are young people and those with middle to upper class income, the students of Petra Christian University can be considered as the suitable target market for this restaurant. Third, college students are known to have flexible schedule and time, which means they are more likely to be able to come to this restaurant on weekdays. Also, they have the desire to explore new things, such as food, place, experience, etc., more than adults do, so the chance for them to be attracted to come to this restaurant is higher. These facts make them the perfect target market for this restaurant to overcome the problem regarding the low number of customers coming on weekdays. Nevertheless, this research will help in finding out the insight and factors that can be used to attract the students of Petra Christian University as the new potential target market to come to this restaurant on weekdays. Furthermore, the writer will also design a digital poster as one example of the promotional tools to deliver the promotions or special offers based on the result of the questionnaire forms back to the respondents. 
Furthermore, there are some principles used to complete this research and the whole Business Communication Final Project. The main principles used are the principle of marketing research, the elements of marketing mix, and the affect of gender role in consumer behavior. First of all, the principle of how to do a marketing research is used as the guideline for the steps I did to complete this project as well as the kind of tool I decided to make as the final outcome, which is the research report. I also used the format of my marketing research report based on the explanation mentioned by careerana (2016), a website focuses on the use of English for academic purposes for students in higher education, which stated that a standard report writing should include title, summary, introduction, body, conclusion and recommendations as the main elements to structure a research report. However, there are actually some elements that I changed on my research report, such as excluding the summary part and focusing the background of my project on the introduction section, changing the body section into findings and discussion, and having the appendice section at the of the report that contains the other additional information and findings I got from the research.

Moreover, the principle of the elements of marketing mix are used to come up with the questions I included on the questionnaire form. There are four variables that one should understand first before adapting the marketing mix. Those four variables are known as the 4 (four) Ps. According to Hunt and Mello (2015, pp.10-12), the 4Ps stand for product, price, place and promotion. Each of these elements holds an important role in a successful marketing effort. The first element of marketing mix is product. Product is a specific combination of goods, services, or ideas that a firm offers to consumers. In this case, product is not only used to describe the tangible characteristic of a brand, such as the engine, tires, seats and other parts of an automobile, but also the intangible characteristic, which includes the navigation system, warranty and service of an automobile when someone purchases it. There are also services, such as those provided by an attorney or electrician, or ideas, like those offered by a consultant as the combination of a product offered by a business. The second element is price. Price is the amount of something, in the form of money, time, or effort that a buyer exchanges with a seller to obtain a product. A product with higher price is often seen as the one with the best quality. In addition, pricing is typically the easiest marketing mix element to change, making it powerful tool for firms looking to quickly adjust their market share or revenue. The next element is place. Place is one of the most remarkable parts of marketing. It includes the activities a firm undertakes to make its product available to potential consumers. Companies must be able to distribute products to customers where they can buy and consume them without difficulty. Place decisions relate to locations, transportation, logistics, and managing the supply chain. The last element in marketing mix is promotion. Promotion is all the activities that communicate the value of a product and persuade customers to buy it. Promotion includes advertising, public relations, personal selling, and sales promotion. As is the case with every element of the marketing mix, successful promotion involves the firm's ability to integrate these activities in a way that maximizes the value of each. An integrated approach will always be important to the success of a promotional strategy, but in the recent years, the way a firm executes its promotional activities has evolved. Today, firms of all sizes and industries can communicate quickly and directly with their customers using a variety of online and digital tools, such as smartphone apps and social media.

Nevertheless, the principle of gender role in consumer behavior is used as the justification for having more female students to be my respondents. This principle stated that according to Peter and Olson (2008, p.325), in the late 1990s, more marketers began to see women as distinctive subculture and bigger key market segment than men. Women control approximately 60 percent of U.S. wealth and influence more than 80 percent of all purchases. Moreover, some 25 percent of working women bring home bigger paychecks than their husbands. This led Tom Peters, a well-known business author to decline that "Women are opportunity No. 1". In some markets, the changes during the past quarter-century have been dramatic. For example, women 
contributed only about 1 percent of all business travelers in 1970, but they accounted for roughly 50 percent by 1997. Recently executives were surprised to find that 60 percent of customers to a do-it-yourself building supplies chain were women and about two-thirds of PC purchases for the home were made by women. Today women either make or greatly influence most purchasing decisions, and companies that do not recognize this are headed for trouble. This research is used to support my decision to have more female students to be my respondents.

\section{METHODS}

In this research, I decided to use a questionnaire form as the main tool to get the insight from my respondents. I distributed the questionnaire forms using two methods. The first one is by using Google forms containing the preliminary questions to get the idea whom I can choose to be included on the fifty main respondents I was looking for and to divide my respondents into those who have been to this restaurant and those who have never been to this restaurant before. I got a total of 185 respondents from the Google form, then I chose fifty of them to be the main respondents to fill out the questionnaire forms in person. I chose the fifty respondents by looking at their answers on the preliminary questions, especially the one that asked for their impressions regarding 'eating in a restaurant located in a hotel' and whether it is interesting or not for them. I chose those who considered 'eating in a restaurant located in a hotel' as an interesting thing to be my respondents. After that, I divided the fifty respondents into seventeen majors with the middle to upper class tuition fees that I have chosen beforehands, so I have three persons to be the representatives of each major. I also chose the more female students to be my respondents. This principle supported my decision to have more female students to be my respondents on this research.

Furthermore, I asked my respondents to meet with me in person to fill out the questionnaire forms, recheck their answers directly, and have brief interviews for some of the answers that are still unclear or wrongly understood. Overall, I met most of them in the university, and I was able to compile the answers from the fifty respondents in a week period of time. The findings that I got from the research will be summarized in a research report as the final outcome of my project. In addition, I will also make a digital poster by the end of this project as one example of the promotional tools that can be used to reach out to the new target market. The digital poster will contain one of the recommendations of special offer that I included on the research report. Moreover, the findings regarding the factors that can be used to attract the students of Petra Christian University based on my research are presented as follows.

\section{FINDINGS AND DISCUSSION}

Throughout the research that I have done by using questionnaire form as the main tool and the students of Petra Christian University as the main respondents, I have been able to gain several important information, which are the cause of the problem happened on this restaurant and the factors that can attract the students of Petra Christian University as the new target market to come to this restaurant. The main cause of the problem that I can conclude from my research is the inability of the management of Seventeen Skyview Resto \& Lounge to identify the suitable target market to be attracted to come on weekdays, which results in the low number of customers coming to this restaurant on weekdays. In many cases, identifying target market should be among the first things that a person needs to prepare to have a stable performance in a business and deliver the right message to the public. Being able to identify the right target market can lead to the right strategy to meet the customers' needs and wants, which is the ultimate goal in every business. In this case, one of the objections that the existing customers may have for not being able to come on weekdays to this restaurant is because of the time. It refers to the daily schedules that most people have; for instance, employees or working people 
need to work 8 hours a day, students have to go to school early in the morning until late in the afternoon or evening and still have to prepare for tomorrow's schedule afterward. Therefore, these target market do not have the time to come to this restaurant on weekdays, even if they want to. That results in their decisions to come to this restaurant on weekends as they only have free time during these days within a week, which leads to the unstable number of customers coming to this restaurant on weekdays and weekends. This restaurant only gets a few customers on weekdays and a lot of them on weekends. Therefore, the management cannot use the same target market to be attracted to come on weekdays and weekends, and in order to get more customers coming on weekdays, there is a need to conduct a research to identify the new potential target market that can become the suitable customers to come on weekdays, which are in this case, happened to be the students of Petra Christian University based on the reasons I have mentioned before.

In addition to that, there are several factors that Seventeen Skyview Resto \& Lounge can use to attract the students of Petra Christian University as the new target market to come to this restaurant and overcome their problem regarding the low number of customers coming on weekdays. First of all, according to the result of the research that I have done, out of the fifty students whom I have met and asked to fill out the questionnaire forms, most of them chose the price or harga as the most important factor that can attract them to come to a restaurant. Moreover, when asked about whether they will be willing to come to a restaurant that is giving a special offer with the price range that they have chosen previously, most of the respondents said that they will come, especially because of the special offer and the affordable price. Therefore, I also included several questions regarding the price range that my respondents are willing to spend to get the different types of special offers. Based on the results, there is a different pattern in choosing the price range for each type of special offer, such as the buffet/prasmanan, individual set menu, and the group/family set menu. Below I present the results in a table of finding. I personally think that this finding is important so that the restaurant can match the target market's expectations regarding the price range, and because price is the most important factor that my respondents will consider when choosing a restaurant.

Table 1.1. The Price Range for Each Type of Food-serving

\begin{tabular}{|c|c|c|c|}
\hline \multirow{2}{*}{ Food-serving } & \multirow{2}{*}{ Price Range } & \multicolumn{2}{|c|}{ Score Analysis } \\
\hline & & Total Score & Percentage \\
\hline \multirow{5}{*}{ Buffet/prasmanan } & Rp. $100.000,00$ - Rp. $125.000,00$ per orang & 18 & $36 \%$ \\
\hline & Rp. $126.000,00$ - Rp. $150.000,00$ per orang & 20 & $40 \%$ \\
\hline & Rp. $151.000,00$ - Rp. $175.000,00$ per orang & 9 & $18 \%$ \\
\hline & Rp. $176.000,00$ - Rp. $200.000,00$ per orang & 1 & $2 \%$ \\
\hline & > Rp. $200.000,00$ per orang & 1 & $2 \%$ \\
\hline \multicolumn{2}{|r|}{ Total Respondents } & 50 & $100 \%$ \\
\hline \multirow{5}{*}{$\begin{array}{c}\text { Individual Set } \\
\text { Menu }\end{array}$} & Rp. $100.000,00$ - Rp. $125.000,00$ per paket & 18 & $52,9 \%$ \\
\hline & Rp. $126.000,00$ - Rp. $150.000,00$ per paket & 7 & $20,6 \%$ \\
\hline & Rp. $151.000,00$ - Rp. $175.000,00$ per paket & 4 & $11,8 \%$ \\
\hline & Rp. $176.000,00$ - Rp. $200.000,00$ per paket & 4 & $11,8 \%$ \\
\hline & >Rp. 200.000,00 per paket & 1 & $2,9 \%$ \\
\hline \multicolumn{2}{|r|}{ Total Respondents } & 34 & $100 \%$ \\
\hline \multirow{3}{*}{$\begin{array}{l}\text { Group/Family } \\
\text { Set Menu }\end{array}$} & Rp. $75.000,00-$ Rp. $90.000,00$ per orang & 7 & $43,7 \%$ \\
\hline & Rp. $91.000,00-$ Rp. $125.000,00$ per orang & 7 & $43,7 \%$ \\
\hline & Rp. $126.000,00$ - Rp. $150.000,00$ per orang & 1 & $6,25 \%$ \\
\hline
\end{tabular}




\begin{tabular}{|r|c|c|c|}
$\mid$\begin{tabular}{r|r|} 
Rp. 151.000,00-Rp. 175.000,00 per orang \\
\cline { 2 - 4 } \\
Rp. 176.000,00->=Rp. 200.000,00 per \\
orang
\end{tabular} & 0 & $0 \%$ \\
\hline Total Respondents & $\mathbf{1 6}$ & $\mathbf{1 0 0 \%}$ \\
\hline
\end{tabular}

Second, they considered menu variations or variasi menu as the second most important factor that can attract them to come to a restaurant. It is because when they choose a restaurant, they want to have a lot of options to choose on the menu so that they can taste different kind of food just by visiting one restaurant, and they feel more satisfied that way. Therefore, when asked about the kind of food-serving that they like the most in a restaurant, most of them chose buffet or All-You-Can-Eat as they can eat as much as they want with this type of food-serving. They also mentioned that when thinking of a restaurant located in a hotel, the first thing that comes to their mind is the buffet food-serving system as most restaurants located in a hotel nowadays offer this type of food-serving. Moreover, the results from my questionnaire form regarding the most preferred type of food-serving system and the menu are presented in the tables of findings below as the supports for the second most important factor that my respondents have chosen.

Table 1.2. The Food-Serving System that can be Offered to the Target Market $(N=50)$

\begin{tabular}{|l|l|c|c|}
\hline \multirow{2}{*}{ Food-serving system } & \multicolumn{2}{c|}{ Choice Analysis } \\
\cline { 3 - 4 } \multicolumn{2}{|c|}{} & $\begin{array}{c}\text { Number of } \\
\text { Respondents }\end{array}$ & Percentage \\
\hline$F S_{1}$ & Buffet/Prasmanan & 25 & $50 \%$ \\
\hline$F S_{2}$ & Set menu/Menu paket-an & 8 & $16 \%$ \\
\hline$F S_{3}$ & A la carte/Menu per-orang-an & 17 & $34 \%$ \\
\hline \multicolumn{2}{r}{ Total Respondents } & $\mathbf{5 0}$ & $\mathbf{1 0 0 \%}$ \\
\hline
\end{tabular}

Table 1.3. The Type of Menu that This Restaurant can Offer $(N=50)$

\begin{tabular}{|l|l|c|c|}
\hline \multirow{2}{*}{ Menu } & \multicolumn{2}{|c|}{ Choice Analysis } \\
\cline { 3 - 4 } & \multicolumn{1}{|c|}{$\begin{array}{c}\text { Number of } \\
\text { Respodents }\end{array}$} & Percentage \\
\hline$M_{1}$ & Chinese Food & 27 & $54 \%$ \\
\hline$M_{2}$ & Western Food & 23 & $46 \%$ \\
\hline \multicolumn{2}{r|}{ Total Respondents } & $\mathbf{5 0}$ & $\mathbf{1 0 0 \%}$ \\
\hline
\end{tabular}

Third, most of my respondents chose promosi as the next most important factor to be considered when choosing a restaurant. However, not all kind of promotions are attractive and can work for them. There are several things that they find interesting, and some that are not a match for their lifestyle. Therefore, the management of the restaurant needs to know what to and what not to highlight on the special offers if they want to attract the students to come to this restaurant. One way to get that insight is by conducting a research. In this case, since the restaurant will have my research report by the end of this project they can use that report as the reference to attract my respondents by matching their preferences with the restaurant's upcoming special offer. For instance, as presented on the tables above that the most preferred type of food-serving is the buffet/prasmanan, and the most preferred menu that my respondents chose is the Chinese food menu, then the restaurant can make a special offer with the buffet or probably the All-You-CanEat food-serving system, and a variety of Chinese food menu as the main dishes. Another alternative can be having both the Western and Chinese food menu since menu variation is one 
of the most important factors for my respondents and the difference between those who chose the Chinese and Western food as presented on the table above is not that much.

In addition, many of my respondents also chose ambience as an important factor to consider when choosing a restaurant. When asked for further explanation, those who chose this factor said that they want a place with good ambience so that they can feel comfortable when eating and hanging out with their friends, families, boyfriends or girlfriends, or simply just by themselves. Nevertheless, they feel like when eating in a restaurant located in a hotel, the ambience should be good because hotels that are known to have good ambience and service are more preferable than the ones that do not. Therefore, those factors become their concern when choosing a restaurant. In addition, these findings will be used as the important points to emphasize on the digital poster that I will make later on. The same rules also apply for this restaurant, they can use these findings as the references in designing the special offer and other important details to be included to attract the students of Petra Christian University on weekdays in the future.

Those are the four most important factors that my respondents consider crucial and important in choosing a restaurant to eat out or simply hangout based on the research that I have done. I believe that those factors and the respondents' opinions about each of the factors can help the Seventeen Skyview Resto \& Lounge to understand more about the insight of young people, in this case represented by the students of Petra Christian University toward a restaurant. Therefore, by considering those factors and designing the suitable offers that can match each factor, also using the right tool to deliver the message to the target market, I believe that this restaurant will be able to overcome its problem regarding the low number of customers coming on weekdays by having the new potential target market.

\section{CONCLUSION}

In conclusion, for my Business Communication Final Project (BCFP), I decided to conduct a research to identify the factors that can be used to attract the students of Petra Christian University as the new potential target market of Seventeen Skyview Resto \& Lounge to come on weekdays. I decided to go with this project as a response to the problem I found in the restaurant of the company where I did my internship, which is HARRIS-POP! Hotels \& Conventions. In short, the problem that I found in this restaurant is regarding the low number of customers coming to the restaurant on weekdays. The gap between the number of customers coming on weekdays and weekends to this restaurant is quite huge. Therefore, I decided to have a closer examination to this problem. As I look further into problem by asking some of the important players of the restaurant regarding the situation and the cause of it, no one was actually sure with the exact cause of this problem. There are only several possible causes that they can explain while I was asking for further information. Those possible causes include the market review, that refers to the needs of people nowadays that keep on changing, such as the need for instagram-able spots, interesting special offers, etc., and because the restaurant cannot seem to provide those needs, they get less attention from the public. Also, the lack of research and survey in identifying the possible target market that can be attracted to come to this restaurant on weekdays is one of the possible causes. In fact, the restaurant has never conducted surveys on their existing customers either; therefore, they get lack of information regarding their performance from the customers' point of view, that makes this restaurant unable to meet the customers' needs, especially during the weekdays. Therefore, I want to help the restaurant to overcome this problem by finding the possible target market that is suitable for this restaurant during the weekdays, and conduct a research to see the insight of this target market, so that the restaurant can have more understading of their needs and be able to attract them by using the suitable form of special offer and tool. 
This intention led me to the decision to do the research using questionnaire form as the main tool and students of Petra Christian University as the main respondents. From the research, I got to discover the insight of the students of Petra Christian University toward this restaurant, especially the factors that can make them be attracted to come and the underlying cause of the problem. Therefore, this restaurant can now have a deeper understanding on how to attract the students of Petra Christian University, which are the new potential target market for this restaurant to come on weekdays. All of my findings from the research are summarized on a research report as the final outcome of my project. This report will be given to the representative of the restaurant and the hotel by the end of my final project so that they can use it a reference and guideline to fulfill the needs of the new target market and boost their performance on weekdays. In addition, I will also make a digital poster containing my idea to promote the special offer based on the recommedations I included on the last part of the research report. This digital poster is only as an example of the tools that this restaurant can use to reach out to the new target market. Later, they can use my findings on the report to make another form of special offer and tool.

I do hope that the management of this restaurant will be able to use this tool appropriately and effectively to solve the problem they are facing on the weekdays and be able to have a stable performance on weekdays and weekends. I also hope that with this research report, they can consider to conduct more surveys or research to always meet the customers' needs and what they want from the restaurant, because the needs and wants of people are things that we cannot control. It changes rapidly along with the growth of technology. This research that I made may be able to give the restaurant the insight of the new target market, students of Petra Christian University now, but it can change soon or later. Therefore, there is always a need for survey and research to see whether a market is still suitable with the products that we provide or not, so that we can always serve the customers with what they want and they will keep on coming back to us. That way, both parties can provide profits for one another.

\section{REFERENCES}

Hunt, S. C., \& Mello, E. J. (2015). Marketing. NY: McGraw-Hill Education.

Peter, P. J., \& Olson, C. J. (2008). Consumer behavior \& marketing strategy. ( $8^{\text {th }}$ ed.). NY: McGraw-Hill Companies, Inc.

Report writing format and sample report. (2016, June 10). Retrieved July 1, 2019, from https://www.careeranna.com/articles/report-writing-format-sample-report/ 